\title{
Analysis Of Annular Raft Foundation using Finite Element Method
}

\author{
Shaik Subhani ${ }^{1}$ and M. Manivannan ${ }^{2}$ \\ ${ }^{1}$ Former Post Graduate student, ${ }^{2}$ Associate Professor, Department of Civil Engineering, \\ PSG College of Technology, Coimbatore, India. \\ \{ subhani.sk642@gmail.com,mmv.civil@psgtech.ac.in\}
}

\begin{abstract}
A finite element analysis of an annular raft and a circular raft is undertaken in this work. Different ratios of inner radius to outer radius are chosen to examine the effect of geometrical characteristics of annular rafts. The ratio of radius of ring beam to outer radius of raft was also varied. Finite element method is adopted to determine critical moments and deflections in both annular and circular rafts. Comparison of these critical moments and deflections is made for both annular raft and circular raft,for selection of suitable type of raft foundation. Finite element analysis of both the rafts is carried out using ANSYS software. The results show that values of critical moments and deflections in annular raft are less in comparison with those values in circular raft. Different ratios of inner radius to outer radius and radius of ring beam to radius of raft effect critical moments and deflections.
\end{abstract}

Keywords: Annular raft, Circular raft, Finite element method, Critical moments and deflections.

\section{Introduction}

Circular tower shaped structures find common application in a variety of modern fields like TV towers, microwave towers, chimneys, cooling towers and over head water tanks etc. The main loads to which these structures are subjected are gravity loads, wind forces and seismic forces. Vertical loads to be transferred in the first four types of towers listed above are relatively much smaller as compared to those in over head water towers. All these loads to which the towers are subjected are ultimately to be transmitted to the foundation and from foundation to the earth. Thus the selection of suitable type of foundation is as important as the shape of tower itself for economical and safe design of overall structure.

Economy and ease of construction determine the suitability of the foundation. The raft foundations are, therefore, most suitable for the towers transferring moderate loads to foundation and for towers of medium height. Thus, they find an extensive application in foundations for water towers. Bearing capacity of soil is an important parameter to decide the size of raft foundation. The raft may be either solid or annular. For relatively large horizontal forces the use of annular raft foundation will be more economical than solid raft because it offers more resistance to overturning. In the annular raft the location of ring beam through which the loads are transferred to the raft is another important factor which governs the economy of such rafts. Location of ring beam is generally fixed and depends upon the size of tower staging. Thus fixing the location of ring beam indirectly leads to proportioning of the 
raft in such a way that the resultant of soil pressure exerted on the raft does not become eccentric to the ring beam and the moments in the raft slab are minimized.

Present study primarily focused on the determination of critical moments and deflections in both annular raft and circular raft using finite element analysis approach, and comparison is made between these two types of rafts for selection of suitable type of foundation. The effect of geometrical characteristics of annular rafts on these critical moments and deflections, such as varying ratios of inner radius to outer radius and the ratio of ring beam radius to outer radius of raft, was also investigated.

\section{Literature Review}

Swathe A and Vishnu M Parkas [1] conducted a soil structure interaction research on a $200 \mathrm{~m}$ reinforced concrete chimney with annular raft foundation under along-wind load. The influence of various height-to-base-diameter ratios (slenderness ratios) on the geometrical attributes of chimneys is investigated. The ratios of the annular raft's outer diameter to its thickness are also altered. Below the foundation, a variable soil profile is considered to better understand the influence of soil flexibility on the annular raft. Three separate soil strata were chosen for examination beneath the foundation. In this work, wind loads were computed using IS: 4998-1992. The ANSYS software is used in this project.

A.N.Kamble, Prof Dr.S.S.Patil [2], had studied the effects of footing size, ring radii ratio of ring foundation and load eccentricity by means of centrifuge modeling, the method of characteristics and the finite element technique. In this study ten different models of ring foundations were modeled and analyzed. The first of the model footings were circular, the others were ring footings. The experimental results indicate that the bearing capacity of the ring footings is depending directly on the ratio of the inside to outside radii, i.e. radius ratio.

Hider Hamada Gaye Al Quincy [3] investigated reinforced concrete ring beams using a nonlinear finite element method (NLFEA). The ultimate strength, mechanism of failure, crack pattern, and deformed shape of three reinforced concrete ring beams supported on four evenly spaced columns are assessed and projected using non linear finite element analysis software. All ring beams have the identical geometrical and material features, with the exception of cross sectional depth and reinforcement quality. The failure mechanisms of ring beams are dictated by their (depth/span) ratio, according to NLFEA statistics.

Abdulsamee Halahla [4] investigated the behavior of a reinforced concrete beam using Finite Element Analysis. The load-deflection response of reinforced concrete beams was investigated using finite element analysis. The finite element analysis findings are compared to the experimental results. Finite element software was utilized to model the reinforced concrete beam and conduct nonlinear static analysis.Stress and deflections from the finite element approach near the centerline of the beam were found to be in good agreement with actual data from a reinforced concrete beam and an analytical model produced using the energy method. The failure load predicted by finite element analysis is extremely close to the failure load obtained during experimental testing. 


\section{Methodology}

Circular slab as Plate:Raft is supposed to be a plate loaded from the bottom and supported at the ring beam. The load may either be uniform or of varying intensity as the case may be. Theory of Elasticity of plates is used for the analysis. For the analysis by plate theory the solution of Fourth order differential equation is required. But in the analysis carried out by the plate theory it becomes very difficult to account for the varying thickness of plate and a close form solution is generally not available. Secondly the effect of width of ring beam in the design forces cannot be accounted for. At the same time the interaction with the complicated boundaries and the width of supports as provided by elastic ring beams cannot be considered in the analysis by plate theory. As such the numerical analysis becomes a necessity for obtaining realistic values of the design forces. The Finite Element Method is one of the most efficient computer methods for accounting for a variety of variables such as varying thickness, varying elastic characteristics of materials, and the effect of the breadth of interacting barriers such ring beam and soil structure interaction. The flexural characteristics of an isotropic circular plate are calculated using the Classical Plate Theory (CPT). The following are the numerous plate cases that are being explored for this study:-

a) Uniform pressure on a circular plate supported on a ring support.

b) Uniform pressure on an annular plate supported on a ring support.

The following are the standard values that are expected at the start of any study project:

Poisson's ratio of concrete $(v)=0.2$

Grade of concrete $=$ M25

Young's modulus of concrete $(\mathrm{E})=25000 \mathrm{MPa}$

Verticalload $(\mathrm{p})=15000 \mathrm{KN}$

Thickness of raft $(\mathrm{h})=0.5 \mathrm{~m}$

Outer radius of raft $(\mathrm{r} 2)=5 \mathrm{~m}$

The inner radius to outer radius ratio of an annular raft can be $0.1,0.2,0.3,0.4$, or 0.5 . For various ratios of the raft's inner to outer diameter, deflections and bending moments are estimated. Table 1 shows the geometrical features of various types of rafts.

\section{GDE (Governing Differential Equation) of symmetrical circular plate bending:}

$$
\frac{d^{3} w}{d r^{3}}+\frac{1}{r} \frac{d^{2} w}{d r^{2}}-\frac{1}{r^{2}} \frac{d w}{d r}=\frac{Q}{D}
$$

In other form it can be written as

$$
\frac{d}{d r}\left[\frac{1}{r} \frac{d}{d r}\left(r \frac{d w}{d r}\right)\right]=\frac{Q}{D}
$$

Table 1.Geometrical features of several raft types.

\begin{tabular}{|l|l|l|l|l|l|l|}
\hline $\begin{array}{l}\text { Outer } \\
\text { radius } \mathrm{r}_{2} \\
(\mathrm{~m})\end{array}$ & $\begin{array}{l}\text { Inner } \\
\text { radius } \mathrm{r}_{1} \\
(\mathrm{~m})\end{array}$ & $\mathrm{r} 1 / \mathrm{r} 2$ & $\begin{array}{l}\text { Radius of ring } \\
\text { beam } \mathrm{r}_{\mathrm{a}} \\
(\mathrm{m})\end{array}$ & $\begin{array}{l}\text { Area of } \\
\text { raft } \\
\mathrm{A} \\
\left(\mathrm{m}^{2}\right)\end{array}$ & $\begin{array}{l}\text { Load on } \\
\text { raft R } \\
(\mathrm{kN})\end{array}$ & $\begin{array}{l}\text { Pressure applied } \\
\text { on Raft } \\
\mathrm{P}=\mathrm{R} / \mathrm{A} \\
\left(\mathrm{kN} / \mathrm{m}^{2}\right)\end{array}$ \\
\hline
\end{tabular}




\begin{tabular}{|l|l|l|l|l|l|l|}
\hline 5 & 0 & 0 & 3.500 & 78.540 & 15000 & 190.986 \\
\hline 5 & 0.5 & 0.1 & 3.500 & 77.754 & 15000 & 192.916 \\
\hline 5 & 1 & 0.2 & 3.575 & 75.398 & 15000 & 198.944 \\
\hline 5 & 1.5 & 0.3 & 3.625 & 71.471 & 15000 & 209.875 \\
\hline 5 & 2 & 0.4 & 3.750 & 65.973 & 15000 & 227.366 \\
\hline 5 & 2.5 & 0.5 & 3.825 & 58.905 & 15000 & 254.647 \\
\hline
\end{tabular}

\section{ANSYS Solution}

ANSYS APDL is used to study circular and annular rafts. ANSYS is a numerical technique-based software that uses finite element analysis. ANSYS APDL is used to represent the plate geometry. For circular plate analysis, a Shell 281, 8 noded element is employed It works well with thin to moderately thick shell constructions. The element has eight nodes, each with six degrees of freedom, as well as translations in the $\mathrm{x}, \mathrm{y}$, and $\mathrm{z}$ axes and rotations around the $\mathrm{x}, \mathrm{y}$, and z-axes. It is ideal for nonlinear linear, huge rotation, and/or large strain applications. Nonlinear analysis takes into account changes in shell thickness. This factor accounts for the follower (load stiffness) effects of distributed pressures .Logarithmic strain and actual stress measurements are used in the element formulations. Membrane strains are limited by the element kinematics (stretching). The curvature variations within a time interval, on the other hand, are believed to be minor. For the purposes of this study, deflections and bending moments are estimated for a variety of instances. Mesh is created using a mapped mesh with a triangle element. The analytical solutions are used to validate the ANSYS results (i.e. CPT results). Figure 1 shows the finite element models of the annular and circular rafts.

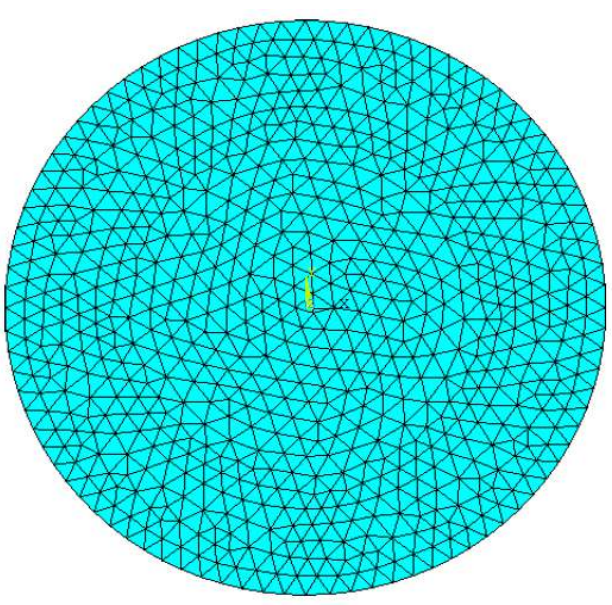

(a)

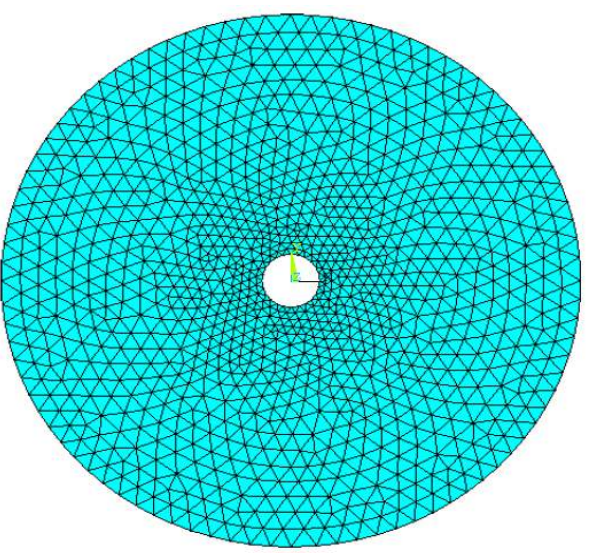

(b)

Fig 1. FEM model of various types of raft a) circular raft b) annular raft 
Table2. Comparison of analytical technique and ANSYS deflection and bending moments for annular raft subjected to UDL.

\begin{tabular}{|c|c|c|c|c|c|c|c|c|}
\hline \multirow[t]{2}{*}{$\begin{array}{l}\mathrm{r} 1 / \mathrm{r} \\
2\end{array}$} & \multirow{2}{*}{$\begin{array}{l}\text { Radiu } \\
\mathrm{s} \text { of } \\
\text { ring } \\
\text { beam } \\
\text { ra } \\
(\mathrm{m})\end{array}$} & \multirow{2}{*}{$\begin{array}{l}\text { Unifor } \\
\mathrm{m} \\
\text { pressur } \\
\text { e P } \\
\left(\mathrm{kN} / \mathrm{m}^{2}\right)\end{array}$} & \multicolumn{2}{|l|}{$\begin{array}{l}\text { Maximum } \\
\text { deflection } \\
(\mathrm{mm})\end{array}$} & \multicolumn{2}{|c|}{$\begin{array}{l}\text { Maximum Radial } \\
\text { Moment MR } \\
(\mathrm{kN}-\mathrm{m})\end{array}$} & \multicolumn{2}{|c|}{$\begin{array}{l}\text { Maximum } \\
\text { Tangential Moment } \\
\text { MT } \\
(\mathrm{kN}-\mathrm{m})\end{array}$} \\
\hline & & & $\begin{array}{l}\text { Analytica } \\
1\end{array}$ & $\begin{array}{l}\text { ANSY } \\
\text { S }\end{array}$ & $\begin{array}{l}\text { Analytica } \\
1\end{array}$ & $\begin{array}{l}\text { ANSY } \\
\text { S }\end{array}$ & $\begin{array}{l}\text { Analytica } \\
1\end{array}$ & $\begin{array}{l}\text { ANSY } \\
\text { S }\end{array}$ \\
\hline 0.1 & 3.500 & 192.916 & 2.2982 & 2.2993 & 171750 & 172000 & 79300 & 79800 \\
\hline 0.2 & 3.575 & 198.944 & 2.0359 & 2.0369 & 170899 & 171000 & 75100 & 75600 \\
\hline 0.3 & 3.625 & 209.875 & 1.7653 & 1.7654 & 154650 & 155000 & 73200 & 73800 \\
\hline 0.4 & 3.750 & 227.366 & 1.2810 & 1.2819 & 129880 & 130000 & 50150 & 50700 \\
\hline 0.5 & 3.825 & 254.647 & 1.1219 & 1.1220 & 111950 & 112000 & 50050 & 50900 \\
\hline
\end{tabular}

Table3. Comparison of deflections and bending moments for annular raft and circular raft.

\begin{tabular}{|c|c|c|c|c|c|c|c|c|c|c|c|}
\hline \multirow[t]{2}{*}{$\begin{array}{l}\text { Type } \\
\text { S of } \\
\text { Raft }\end{array}$} & \multirow{2}{*}{$\begin{array}{l}\text { Out } \\
\text { er } \\
\text { radi } \\
\text { us } \\
\text { r2 } \\
(\mathrm{m})\end{array}$} & \multirow{2}{*}{$\begin{array}{l}\text { Inn } \\
\text { er } \\
\text { radi } \\
\text { us } \\
\text { r1 } \\
(\mathrm{m})\end{array}$} & \multirow[t]{2}{*}{$\begin{array}{l}\text { Are } \\
\text { a of } \\
\text { raft } \\
\text { A } \\
\left(\mathrm{m}^{2}\right)\end{array}$} & \multirow{2}{*}{$\begin{array}{l}\text { Unif } \\
\text { orm } \\
\text { press } \\
\text { ure } \mathrm{P} \\
(\mathrm{kN} / \\
\left.\mathrm{m}^{2}\right)\end{array}$} & \multirow{2}{*}{$\begin{array}{l}\text { Rad } \\
\text { ius } \\
\text { of } \\
\text { ring } \\
\text { bea } \\
\text { m ra } \\
\text { (m) }\end{array}$} & \multicolumn{2}{|c|}{$\begin{array}{l}\text { Maximum } \\
\text { deflection } \\
(\mathrm{m})\end{array}$} & \multicolumn{2}{|c|}{$\begin{array}{l}\text { Maximum } \\
\text { Radial } \\
\text { Moment MR } \\
(\mathrm{kN}-\mathrm{m})\end{array}$} & \multicolumn{2}{|c|}{$\begin{array}{l}\text { Maximum } \\
\text { Tangential } \\
\text { Moment MT } \\
(\mathrm{kN}-\mathrm{m})\end{array}$} \\
\hline & & & & & & $\begin{array}{l}\text { Analyt } \\
\text { ical }\end{array}$ & $\begin{array}{l}\text { ANS } \\
\text { YS }\end{array}$ & $\begin{array}{l}\text { Analyt } \\
\text { ical }\end{array}$ & $\begin{array}{l}\text { ANS } \\
\text { YS }\end{array}$ & $\begin{array}{l}\text { Analyt } \\
\text { ical }\end{array}$ & $\begin{array}{l}\text { ANS } \\
\text { YS }\end{array}$ \\
\hline $\begin{array}{l}\text { Circ } \\
\text { ular }\end{array}$ & 5 & 0 & $\begin{array}{l}78.5 \\
40\end{array}$ & $\begin{array}{l}190.9 \\
86\end{array}$ & 3.5 & 2.2222 & $\begin{array}{l}2.24 \\
87\end{array}$ & $\begin{array}{l}18260 \\
0\end{array}$ & $\begin{array}{l}1830 \\
00\end{array}$ & $\begin{array}{l}12970 \\
0\end{array}$ & $\begin{array}{l}1300 \\
00\end{array}$ \\
\hline $\begin{array}{l}\text { Ann } \\
\text { ular }\end{array}$ & 5 & 0.5 & $\begin{array}{l}77.7 \\
54\end{array}$ & $\begin{array}{l}192.9 \\
16\end{array}$ & 3.5 & 2.2892 & $\begin{array}{l}2.29 \\
93\end{array}$ & $\begin{array}{l}17175 \\
0\end{array}$ & $\begin{array}{l}1720 \\
00\end{array}$ & 79300 & $\begin{array}{l}7980 \\
0\end{array}$ \\
\hline
\end{tabular}

\section{Numerical Results}

The ratio $\mathrm{r} 1 / \mathrm{r} 2$ will depend on the moment of inertia and the bearing area required for footing such that the maximum stress developed does not exceed the safe allowable bearing pressure specified for the soil. For a particular b/a ratio, the value of ra/r2 at which the maximum moments are minimum were obtained from (Fig 2) 


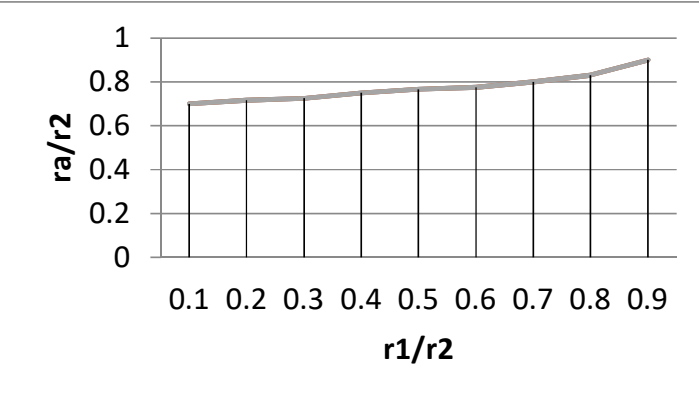

Fig 2. Position of Ring Beam for Minimum Value ofthe Maximum Moments

The analytical technique and ANSYS are compared to obtain flexural parameters such as deflections and bending moments for various examples of an annular raft, as shown in Table 2.Table 3 shows a comparison of deflection and bending moment values in both annular and circular rafts.

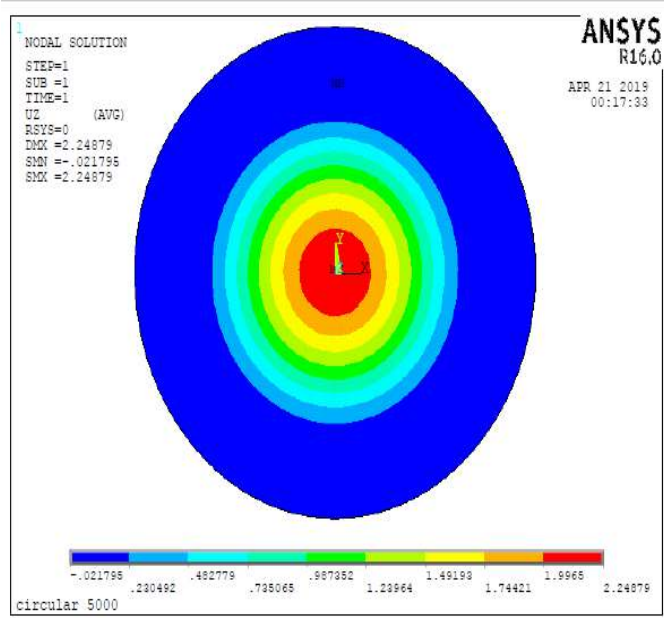

Figure 3. Deflection contour for circular raft 


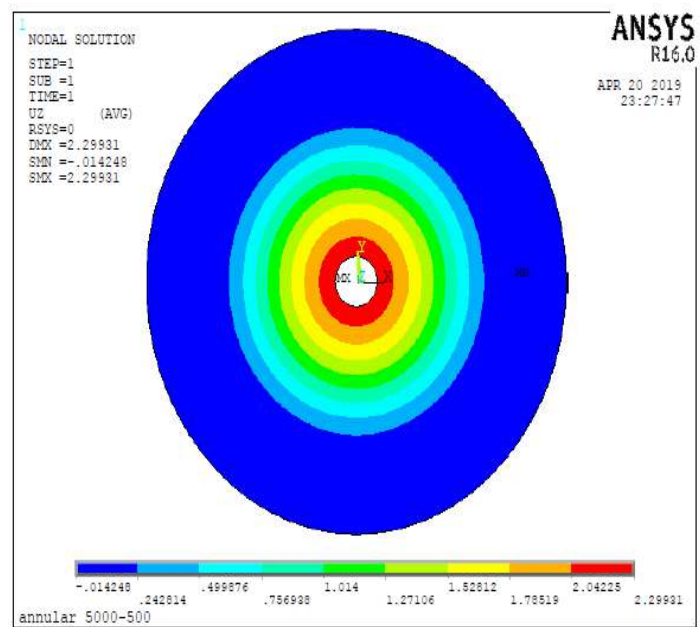

Figure 4. Deflection contour for annular raft

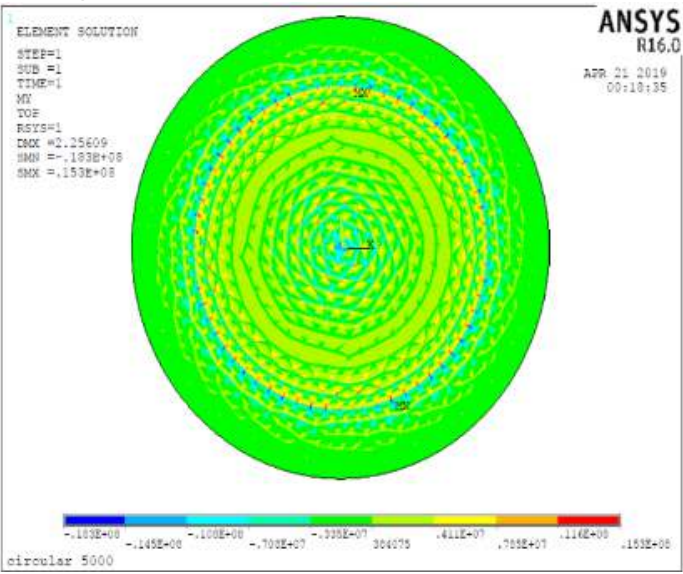

Fig 5. Radial moment contour for circular raft 


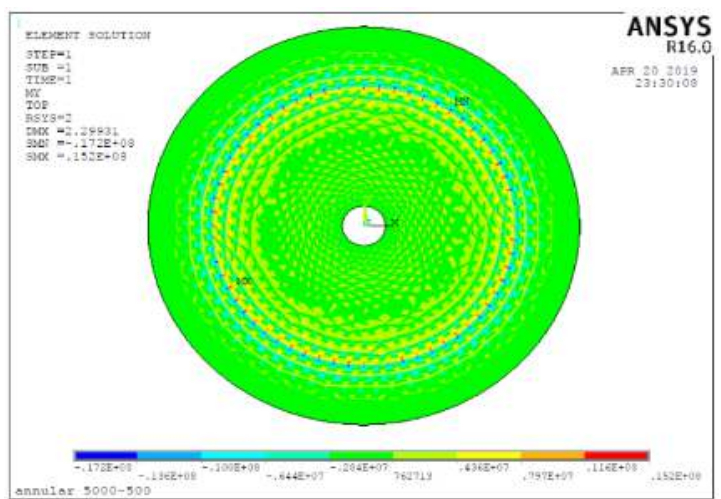

Fig 6. Radial moment contour for annular raft

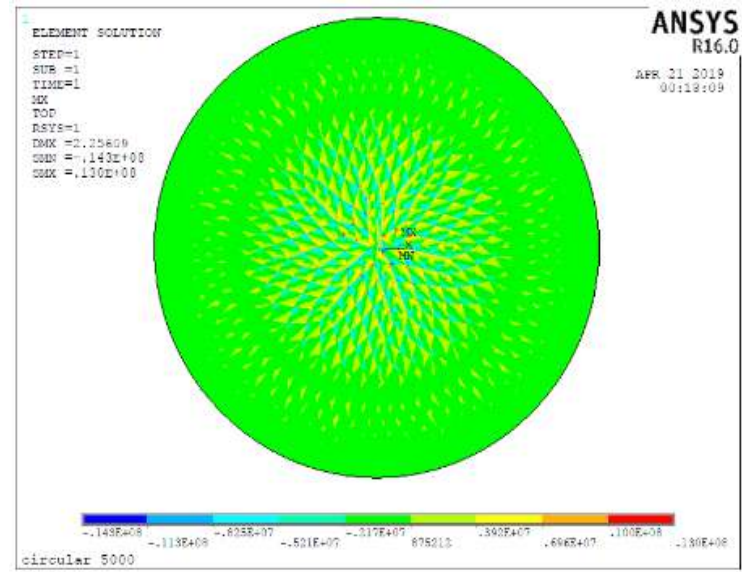

Fig 7. Tangential moment contour for circular raft

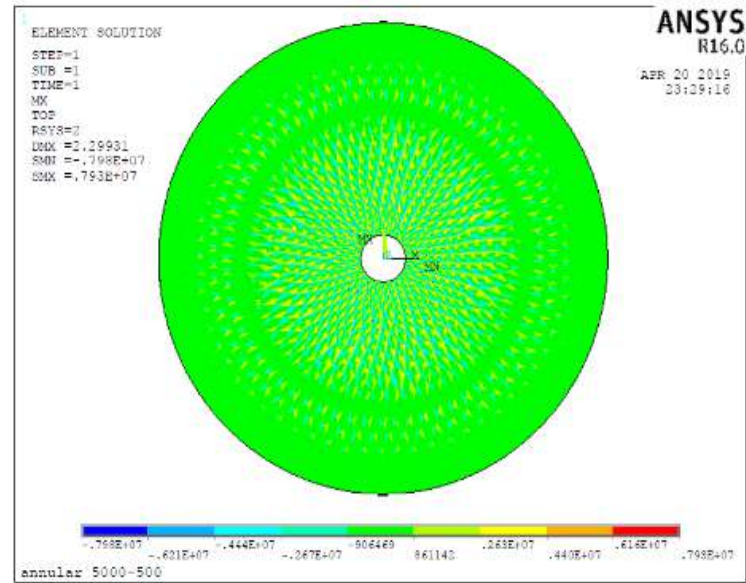

Fig 8. Tangential moment contour for annular raft 


\section{Discussions}

For various ratios of inner radius to outer radius of annular raft, Table 2 compares deflection and bending moments computed using analytical technique and ANSYS. Table 2 shows that the results derived from analytical equations for deflections and bending moments correspond well with the findings obtained from ANSYS. The results from both procedures are substantially identical in 95 to 97 percent of cases. For circular and annular rafts exposed to uniform pressure, Table 3 compares deflection and bending moments determined from analytical and ANSYS simulations. Table 3 shows that the findings of the analytical technique and ANSYS for deflection and bending moments for annular and circular rafts match roughly 95 percent.

For various ratios of inner radius to outer radius of annular raft, Table 2 compares deflection and bending moments computed using analytical technique and ANSYS. The maximum deflection value, as well as the maximum bending moments, increases as the ratio of the inner radius to the outer radius of the annular raft grows; this is due to a reduction in raft area. The product of force and distance is defined as moment.Due to reduction of area, there will be reduction in distance, hence bending moment gets reduced. It can be observed that with reduction in area of annular raft, load to be applied on raft gets increased. This increase in load is related to bearing capacity of soil. Hence selection of suitable type of annular raft depends upon the bending moments developed in raft and bearing capacity of soil.

For circular and annular rafts exposed to uniform pressure, Table 3 compares deflection and bending moments determined from analytical and ANSYS simulations. Results indicate that maximum value of bending moments in annular raft is less in comparison with bending moments in circular raft. This is due to reduction in area of raft and increase in stiffness of raft.

\section{Conclusions}

The parametric analysis of bending moments and defections of circular and annular rafts using analytical methods like as CPT and ANSYS yielded the following results:

1. With increase in ratio of inner radius to outer radius in annular raft, maximum deflection value and maximum bending moment values get reduced.

2. In annular raft, up to ratio of 0.4, maximum deflection occurs at the inner edge of raft. Beyond 0.5 ratios, maximum deflection occurs at the outer edge of raft.

3. In an annular raft, the maximum radial moment occurs at the ring beam location, while the maximum tangential moment occurs at the raft's inner border.

4. Radial moments and tangential moments in annular raft are less in comparison with radial and bending moments in circular raft.

5. Annular raft is more economical to design in comparison with annular raft.

\section{References}

[1] Aswathi A, and Vishnu M Prakash, Sep-2016, "Ssi analysis of tall chimneys with annular raft considering variable soil profile", International journal of engineering sciences \& research Technology, Vol 5(9). 
[2] A.N.Kamble, Prof Dr.S.S.Patil, Feb-2017, "Analysis of Ring Foundation Using Finite Element Method for Various Depth", International Journal of Innovative Research in Science, Engineering and Technology, Vol. 6, Issue 2.

[3] Haider Hamad Ghayeb Al Qaicy, May-2014, "Reinforced Concrete Ring Beams [Non-Linear Finite Element Analysis (NLFEA)]", Journal of Basic and Applied Scientific Research.

[4] Abdulsamee Halahla, Apr-2018,"Study the Behavior of Reinforced Concrete Beam Using Finite Element Analysis",Proceedings of the 3rd World Congress on Civil, Structural, and Environmental Engineering (CSEE'18) Budapest, Hungary,Paper No. ICSENM 103 DOI: 10.11159/icsenm18.103.

[5] Yogesh Rana, Abbas Jamani,Apr-2018,“comparative study of annular raft foundation \& solid circular raft foundation for different diameter of water tank",International Research Journal of Engineering and Technology (IRJET), Volume: 05 Issue: 04.

[6] IS: 11089-1984 (reaffirmed 2002) Code of practice for design and construction of ring foundation, Bureau of Indian Standards, New Delhi.

[7] P. C. Varghese, Design of Reinforced Concrete Foundations,PHI learning privatelimited,2013.

[8] K. Chandrashekhara, Theory of plates, Universities press Private limited, 2013.

[9] S. P. Timoshenko, S. W. Krieger, Theory of plates and shells, McGraw Hill Education Edition 2010.

[10] D. S. Vijayan and J. J. Daniel, "An investigation on the torsional effect of symmetric moment resisting frame system subjected to eccentric reinforced concrete lift wall - A finite element approach," Int. J. Eng. Trends Technol., vol. 69, no. 8, pp. 179-184, 2021, doi: 10.14445/22315381/IJETT-V69I8P222.

[11] D. S. Vijayan, A. Mohan, J. J. Daniel, V. Gokulnath, B. Saravanan, and P. D. Kumar, "Experimental Investigation on the Ecofriendly External Wrapping of Glass Fiber Reinforced Polymer in Concrete Columns," vol. 2021, 2021. 